\title{
CUISINE, CULTURE, AND POLITICS \\ IN RUSSIA AND EASTERN EUROPE: THE FOOD FOR THOUGHT SYMPOSIUM
}

Adrianne K. Jacobs

University of North Carolina

at Chapel Hill
Эдриан К. Джекобс

Университет

Северной Каролины

в Чапел-Химл

E-mail: adri.k.jacobs[at]gmail.com

Copyright: (C) 2014 Jacobs. This is an open-access publication distributed under the terms of the Creative Commons Attribution License (CC BY 4.0), which permits unrestricted use, distribution, and reproduction in any medium, provided the original author and source are credited.

\section{КУАИНАРНОЕ ИСКУССТВО, КУАЬТУРА И ПОАИТИКА В РОССИИ И ВОСТОЧНОЙ ЕВРОПЕ: ПИЩА ДАЯ РАЗМЫШАЕНИЙ}

The Symposium "Food for Thought: Culture and Cuisine in Russia \& Eastern Europe, 1800-Present" was held at the University of Texas at Austin on February 7 and 8, 2014. Mary Neuburger, Tatiana Kuzmic, and Keith Livers, all of UT Austin, organized this event with support from the Center for Russian, East European, and Eurasian Studies, and other local sponsors. With more than fifty presenters, "Food for Thought" represents the largest conference on Russian, East European, and Eurasian food studies ever held in the United States. This event brought together scholars from a range of disciplines, including history, anthropology, literature, and geography, with culinary professionals engaged in promoting and researching these regions' foodways. This was a truly international gathering. "Food for Thought" hosted participants from the United States, Canada, Russia, United Kingdom, France, Bulgaria, Germany, Poland, Czech Republic, and Slovenia.

Dr. Ronald LeBlanc, Professor of Russian and Humanities at the University of New Hampshire, gave the keynote address, "From Russian Vegetarians to Soviet Hamburgers: Tolstoy, Pilnyak, and the Ethics/Politics of Diet." This included material from Dr. LeBlanc's previous monograph, Slavic Sins of the Flesh (2009), and also offered a preview of his forthcoming gastrocritical study of Boris Pilnyak's 1936 novel, Meat. In this talk, Dr. LeBlanc captured one of the unifying themes of the conference. That is, in studying the way people in a given society think 
about, practice, and represent their food culture, scholars can untangle heretofore overlooked aspects of the society's networks of moral, ethical, and aesthetic principles.

The Symposium's fourteen panels covered a wide array of subjects and approaches to the study of food and drink, past and present. For example, a panel titled "In Vino Veritas" addressed the history of wine as a commodity in Russia and Bulgaria, while also connecting the history of viticulture to representations and practices of alcohol consumption in these countries. "Progress in the Kitchen" featured four papers-by Christine Ruane (University of Tulsa), Alice Weinreb (Loyola University of Chicago), Marina Potoplyak (University of Texas Austin), and Emily Hillhouse (Huston-Tillotson University) - that looked at the kitchen as a site for social reform projects throughout the twentieth century. Other themes and approaches ran throughout the conference. Some scholars used the methods of cultural geography to interrogate food customs. Maria Emanovskaya (INALCO Paris) thus explored Soviet Russian food habits in the 1980s, while Kaitlin Lane Fertaly (University of Colorado Boulder) examined domestic skills in postsocialist Armenia. Several participants focused specifically on manifestations of "national" cuisine in the Soviet Union, post-Soviet Russia, Bulgaria, Belarus, and Slovenia. Celebrity chefs provided one entry point into the subject of national culinary identity, as in presentations by Ana Tominc (Lancaster University) and Mary Neuburger. Lynn Visson (Monterey Institute of International Studies) and Nikolai Burlakoff (independent scholar) combined research with personal memories in their presentations on, respectively, Russian restaurants in postwar New York City and the history of borscht. Other presentations considered such diverse topics as food in post-Soviet Russian comics, representations of cannibalism in literature, the daily lives of gypsies, and tourists' meals in socialist Romania.

Presenters and invited attendees also enjoyed several unique gastronomic experiences as part of the symposium. Czech-American chef Pavla von Biber of the August Escoffier School of Culinary Arts in Austin catered lunches and coffee breaks. Friday's lunch centered on chicken paprikash-chunks of chicken in a creamy paprika sauce-served with egg noodles and bread dumplings (knedliky). Lunch on Saturday featured a variety of handmade Czech-style sausages. On both days of the symposium, participants and visitors enjoyed Chef Von Biber's pastries and cakes between panels.

Dr. Glenn Mack, President of Le Cordon Bleu College Atlanta, invited presenters to attend a special event at Le Cordon Bleu Austin on Friday. Dr. Mack demonstrated the art of making hand-pulled noodles, such as those found in Chinese, Uzbek, and other East and Central Asian cuisines. During the presentation, participants enjoyed laghman, a spicy beef noodle soup, prepared in-house by Le Cordon Bleu chefs in training. Afterward the group sampled a selection of infused vodkas and vodka cocktails. 
The symposium closed with a wine tasting and gala dinner. Master Vintner Vance Petrunoff conducted the wine tasting. Participants learned about the history of viticulture in Bulgaria and sampled an array of Bulgarian wines available for sale in parts of the United States. Next came an evening of food and dancing at the Russian House NaZdorovye Restaurant, located at $307 \mathrm{E}$ 5th St in downtown Austin. The meal included a variety of popular dishes from Russia and other parts of the former Soviet Union, including borscht, chakhokhbili (a Georgian chicken stew), and delicate Napoleon cake.

In the weeks following the symposium, participants founded the Association for the Study of Russian, East European, and Eurasian Food and Drink (ASREEEFD). This interdisciplinary community brings together scholars and culinary professionals dedicated to the study of the history, politics, and the culture of food in Eastern Europe and the former Soviet Union. Members of ASREEEFD have since contributed to the creation of the H-Eurasia-Food Network, which launches this fall as a new addition to the H-Net Commons. ASREEEFD plans to organize additional conferences on Russian, East European, and Eurasian food studies in the future. Interested scholars can contact ASREEEFD at adri.k.jacobs@gmail.com. 